\title{
Clinical and pathological variability of infection by enterohaemorrhagic (Vero cytotoxin producing) Escherichia coli
}

\author{
C M HUNT, J A HARVEY, E R YOUNGS, * S T IRWIN, $\dagger$ T M REID
}

From the Department of Histopathology, County Hospital. Lincoln, the *Public Health Laboratory, Lincoln, the $†$ Department of Surgery, Aberdeen Royal Infirmary, Aberdeen, and the $\ddagger$ Bacteriology Laboratory, City Hospital, Aberdeen

SUMMARY The clinical and pathological features of five sporadic cases of enteric infection caused by Escherichia coli 0157 (enterohaemorrhagic or Vero cytotoxin-producing $E$ coli showed a range of features. These included one case with pseudomembranous colitis, one with an acute exacerbation of ulcerative colitis, and three with enterocolitis. Diagnostic difficulties encountered initially in four of the five cases were finally resolved by correlating the results of microbiological with histopathological investigations.

In view of the heterogeneity of clinical and histological signs and symptoms, it is concluded that all patients with abdominal pain and diarrhoea or rectal bleeding should have early microbiological investigation.

The first reports linking Vero cytotoxin-producing E coli (VTEC) (mostly of serotype 0157:H7) with haemorrhagic colitis were published in 1983 and came from North America. 'Since then, outbreaks in institutions such as homes for the elderly ${ }^{23}$ and in the community ${ }^{4}$ have been recognised. Sporadic cases in the United Kingdom and North America have also been described. ${ }^{59}$ Outbreaks have been associated with the consumption of hamburgers ${ }^{3-5}$ and unpasteurised milk, ${ }^{4}$ and VTEC have also been found in samples of cheese, beef, pork, poultry and lamb. ${ }^{70}$

A case control study of a community outbreak in East Anglia suggested that handling vegetables, particularly potatoes, was the important risk factor." Person to person spread has also been suggested as the likely route of transmission from outbreak studies, ${ }^{24}$ and there has been a report of a nurse who acquired VTEC from a patient and developed haemolytic uraemic syndrome. ${ }^{12}$

The association between VTEC and haemolytic uraemic syndrome has been recognised since $1983 .^{13}$ Children and occasionally adults may be affected; in adults this may take the form of thrombotic thrombocytopenic purpura, ${ }^{6}$ which reflects the probable overlap between the two syndromes. This form of haemolytic uraemic syndrome, known as the epidemic form, has prodromal symptoms similar to those of haemorrhagic colitis ${ }^{714-16}$ and usually has a good prognosis. Although none of our cases showed signs of developing this complication, it is still not clear what factors predispose to the development of haemolytic uraemic syndrome following enteric infection with VTEC.

The typical clinical history of haemorrhagic colitis is of an acute self-limiting illness presenting with lower abdominal pain and watery diarrhoea, which later becomes bloodstained and may resemble frank rectal bleeding. The absence of fever or neutrophils in the stool may help to distinguish the syndrome from bacterial dysentery or inflammatory bowel disease. ${ }^{1-81517}$ Infection with VTEC may cause a severe or even fatal illness, especially in the elderly ${ }^{2}$ and in children. ${ }^{914}$ Milder forms of disease are also likely but may not come to medical attention. Few reports of the appearance of colonic or rectal biopsy specimens have been published. ${ }^{61819}$

\section{Material and methods}

All five cases were patients admitted as emergencies to the County Hospital, Lincoln, or the City Hospital, Aberdeen. The case histories are detailed in the table.

For pathological examination the colectomy specimen from case 1 and the biopsy specimens from 
Table Case histories of 5 patients studied

\begin{tabular}{|c|c|c|c|c|c|}
\hline & Case 1 & Case 2 & Case 3 & Case 4 & Case 5 \\
\hline Age and sex & $47 \mathrm{M}$ & $62 \mathrm{M}$ & $27 \mathrm{~F}$ & $23 \mathrm{M}$ & $63 \mathrm{M}$ \\
\hline $\begin{array}{l}\text { Date and } \\
\text { hospital of } \\
\text { admission }\end{array}$ & $\begin{array}{l}29 / 11 / 87 \\
\text { City Hospital } \\
\text { Aberdeen }\end{array}$ & $\begin{array}{l}\text { 14/12/87 } \\
\text { County Hospital } \\
\text { Lincoln }\end{array}$ & $\begin{array}{l}03 / 07 / 87 \\
\text { County Hospital } \\
\text { Lincoln }\end{array}$ & $\begin{array}{l}\text { 09/10/87 } \\
\text { City Hospital } \\
\text { Aberdeen }\end{array}$ & $\begin{array}{l}09 / 01 / 88 \\
\text { City Hospital } \\
\text { Aberdeen }\end{array}$ \\
\hline History & $\begin{array}{l}\text { Abdominal pain, } \\
\text { watery diarrhoea }\end{array}$ & $\begin{array}{l}\text { Abdominal pain, } \\
\text { vomiting, prior } \\
\text { weight loss and } \\
\text { diarnhoea-two } \\
\text { months }\end{array}$ & $\begin{array}{l}\text { Abdominal pain, } \\
\text { diarrhoea }\end{array}$ & $\begin{array}{l}\text { Abdominal pain, } \\
\text { diarrhoea }\end{array}$ & $\begin{array}{l}\text { Abdominal pain, } \\
\text { diarnhoea, rectal } \\
\text { bleeding, general } \\
\text { malaise }\end{array}$ \\
\hline $\begin{array}{l}\text { Duration of } \\
\text { symptoms } \\
\text { before } \\
\text { admission }\end{array}$ & 1 day & 5 days & 4 days & 3 days & 6 days \\
\hline Investigations & $\begin{array}{l}\text { Emergency } \\
\text { gastrograffin enema, } \\
\text { stool culture, } \\
\text { sigmoidoscopy }\end{array}$ & $\begin{array}{l}\text { Stool culture } \\
\text { colonoscopy and } \\
\text { biopsy, barium } \\
\text { enema }\end{array}$ & $\begin{array}{l}\text { Sigmoidoscopy and } \\
\text { biopsy, stool culture }\end{array}$ & $\begin{array}{l}\text { Sigmoidoscopy and } \\
\text { biopsy, stool culture }\end{array}$ & $\begin{array}{l}\text { Sigmoidoscopy and } \\
\text { biopsy, stool culture }\end{array}$ \\
\hline Progress & $\begin{array}{l}\text { Diarrhoea became } \\
\text { blood stained, } \\
\text { worsening } \\
\text { abdominal pain and } \\
\text { peritonism }\end{array}$ & $\begin{array}{l}\text { Grossly bloody } \\
\text { diarnhoea }\end{array}$ & $\begin{array}{l}\text { Diarrhoea became } \\
\text { blood stained, } \\
\text { vomiting }\end{array}$ & $\begin{array}{l}\text { Diarrhoea became } \\
\text { blood stained }\end{array}$ & Gradual recovery \\
\hline $\begin{array}{l}\text { Clinical } \\
\text { impression }\end{array}$ & $\begin{array}{l}\text { Fulminant ulcerative } \\
\text { colitis }\end{array}$ & Colonic carcinoma & Distal colitis & Appendicitis & Acute enterocolitis \\
\hline Final diagnosis & $\begin{array}{l}\text { Pseudomembranous } \\
\text { colitis }\end{array}$ & $\begin{array}{l}\text { Acute exacerbation of } \\
\text { ulcerative colitis }\end{array}$ & Enterocolitis & Enterocolitis & Enterocolitis \\
\hline Treatment & $\begin{array}{l}\text { Emergency subtotal } \\
\text { colectomy, broad } \\
\text { spectrum antibiotics }\end{array}$ & $\begin{array}{l}\text { Intravenous fluids, } \\
\text { Salazopyrine, steroid } \\
\text { enemas }\end{array}$ & Supportive & $\begin{array}{l}\text { Intravenous fluids, } \\
\text { antibiotics }\end{array}$ & Intravenous fluids \\
\hline Follow up & $\begin{array}{l}\text { Uncomplicated } \\
\text { postoperative } \\
\text { recovery }\end{array}$ & $\begin{array}{l}\text { Slow improvement } \\
\text { Colonic biopsy four } \\
\text { months later- } \\
\text { ulcerative colitis }\end{array}$ & Well 10 days later & Well 12 days later & Well 5 days later \\
\hline
\end{tabular}

cases 2-5 were processed routinely and stained with haematoxylin and eosin.

For microbiological investigation faeces were inoculated on to Sorbitol MacConkey agar (Oxoid Limited CM 813) and incubated overnight at $37^{\circ} \mathrm{C}$. Non-sorbitol fermenting colonies were identified using the API 20E system (API bioMérieux UK Limited) and all identified as $E$ coli were tested for agglutination with $E$ coli 0157 antiserum (Public Health Laboratory Service and Difco) using slide and tube techniques. The slide test entailed emulsifying six colonies individually in a loopful of antiserum on a glass slide which was rocked and observed for agglutinatiion. A suspension of organism in saline acted as a control and isolates showing positive or equivocal results were further tested in a microtitre plate. Six colonies were picked individually into $1.5 \mathrm{ml}$ nutrient broth, incubated at $37^{\circ} \mathrm{C}$ for five hours, and then boiled for 30 minutes. Equal volumes of diluted $E$ coli 0157 antiserum in phenol saline and organism suspension were added to wells to give a final volume of $200 \mu \mathrm{l}$ and arrange of antiserum dilution from $1 / 32$ to $1 / 256$. Control wells were set up with equal volumes of organism suspension and phenol saline. After gentle shaking the plate was covered and incubated at $56^{\circ} \mathrm{C}$ overnight. Each well was then examined for agglutination. A known $E$ coli 0157 stain was included in each test. All isolates showing agglutination at $1 / 128$ or greater in test but not control wells were sent to the Division of Enteric Pathogens, Central Public Health Laboratory for confirmation of identity and Vero cytotoxin production.

\section{Results}

\section{PATHOLOGY}

Case 1

Gross examination showed discrete plaques of yellowgreen friable material up to $1 \mathrm{~cm}$ in diameter on the mucosal surface of the caecum and ascending colon. Distal to this, there was a confluent membrane over the mucosa. The bowel wall and serosa were indurated and congested (fig 1). Microscopical examination of the proximal colon showed focal, severe inflammation around superficial parts of disrupted crypts (fig 2). A cap of mucin, fibrin, and neutrophil polymorphs in columns streamed upwards from the crypt bases. Adjacent mucosa showed minimal inflammation and oedema and no distortion of crypt architecture. The distal colon showed almost complete mucosal ulcera- 


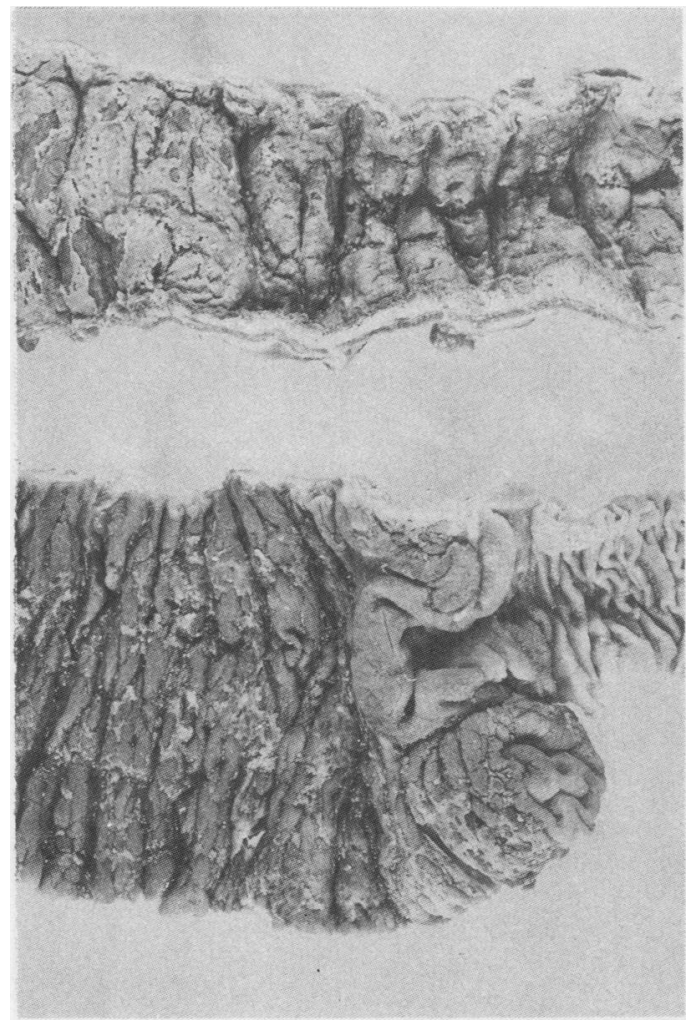

Fig 1 Case 1: plaques over proximal colon (below); membrane over distal colon.

tion covered by inflammatory slough.

The appearances in the proximal colon were typical of types 1 and 2 lesions, pathognomonic of pseudomembranous colitis, and those in the distal colon, of the type 3 lesion. ${ }^{20} 21$

\section{Case 2}

Colonic biopsy specimens showed glandular architecture distortion and atrophy with numerous crypt abscesses (fig 3). No granulomata were seen and there was no evidence of malignancy. A further biopsy specimen taken four months later showed similar appearances, consistent with active ulcerative colitis.

\section{Cases 3, 4, and 5}

Colonic and rectal biopsy specimens showed similar features with neutrophil polymorphs in the lamina propria, some extending into surface and crypt epithelium (fig 4). No glandular architectural abnormalities or granulomata were identified. The appearances were consistent with an acute infective aetiology. No amoebae were identified in any case.

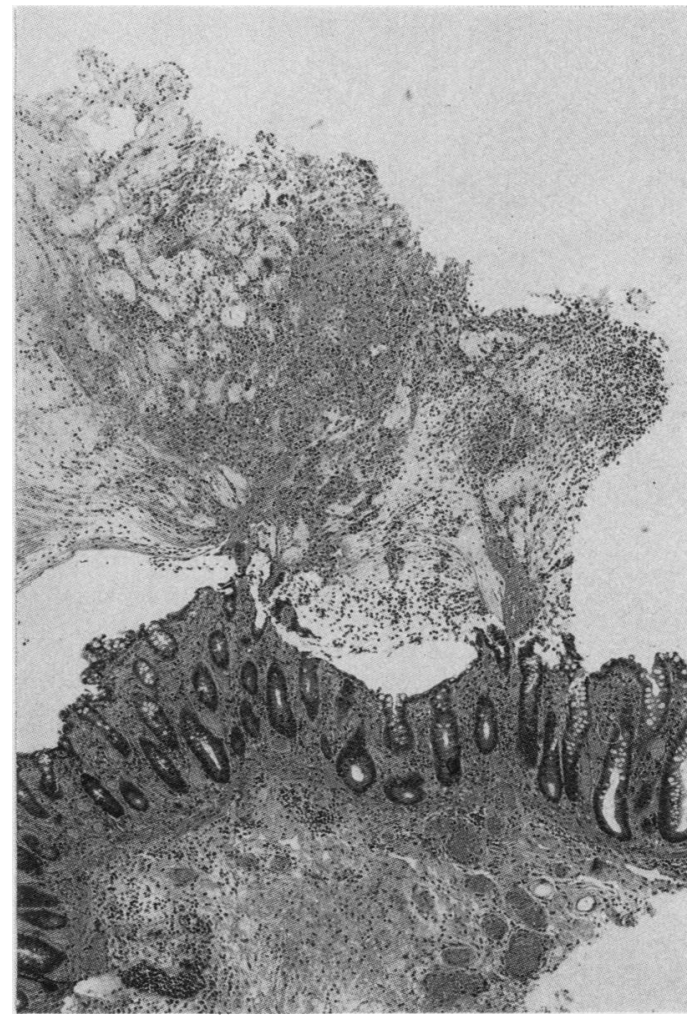

Fig 2 Case 1: typical summit lesion of pseudomembranous colitis.

\section{MICROBIOLOGY}

Stool cultures were performed soon after admission in each case (in the first few days of the acute illness, therefore). A Vero cytotoxin producing $E$ coli 0157 was isolated from the stool in all cases. No salmonella, shigella, campylobacter, aeromonas or yersinia species were isolated. Cryptosporidium ova, cysts, and parasites were not seen. Clostridium difficile was not found in case 1 , nor was toxin detected. In case 2 stool culture six weeks after the acute illness was negative for $E$ coli 0157.

\section{Discussion}

The morphological features of VTEC infection reported to date mostly show non-specific changes of varying severity, consistent with an infective aetiology. $^{18}$ Histological changes of infective enterocolitis, as seen in our cases 3,4 , and 5 , are not specific for the organism involved. Similar features can be seen in infections due to many pathogens, including shigellae. 


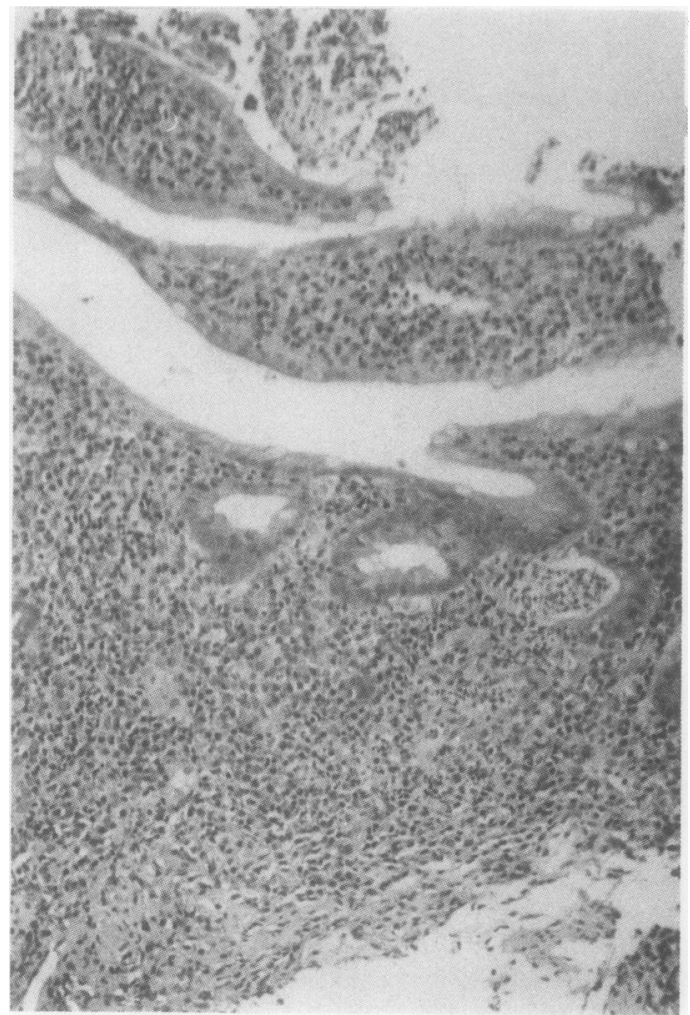

Fig 3 Case 2: severe active ulcerative colitis.

Type 2 mucosal lesions of pseudomembranous colitis, as seen in case 1 , have been reported twice previously in VTEC infection. ${ }^{619}$ Pseudomembranous colitis is usually associated with prior use of broad spectrum antibiotics and the isolation of $C$ difficile or its toxin, but case reports exist which suggest that a range of organisms besides $C$ difficile may cause pseudomembranous colitis, including other clostridia and staphylococci. ${ }^{22-28}$

The diagnosis of ulcerative colitis in case 2 seems well substantiated in view of the appearances of the biopsy specimen, the subsequent course, and response to treatment. Isolation of $E$ coli 0157 from the stool accompanied a pronounced deterioration in the patient's state of only a few days duration; a later stool culture was negative for the organism. It would therefore seem reasonable to attribute this acute exacerbation to enteric infection.

Cases 3, 4, and 5 had similar clinical findings, which, in retrospect, are in keeping with previous descriptions of haemorrhagic colitis. ${ }^{1-81517}$ Only in case 5, however, was acute enterocolitis diagnosed initially. Case 3 was

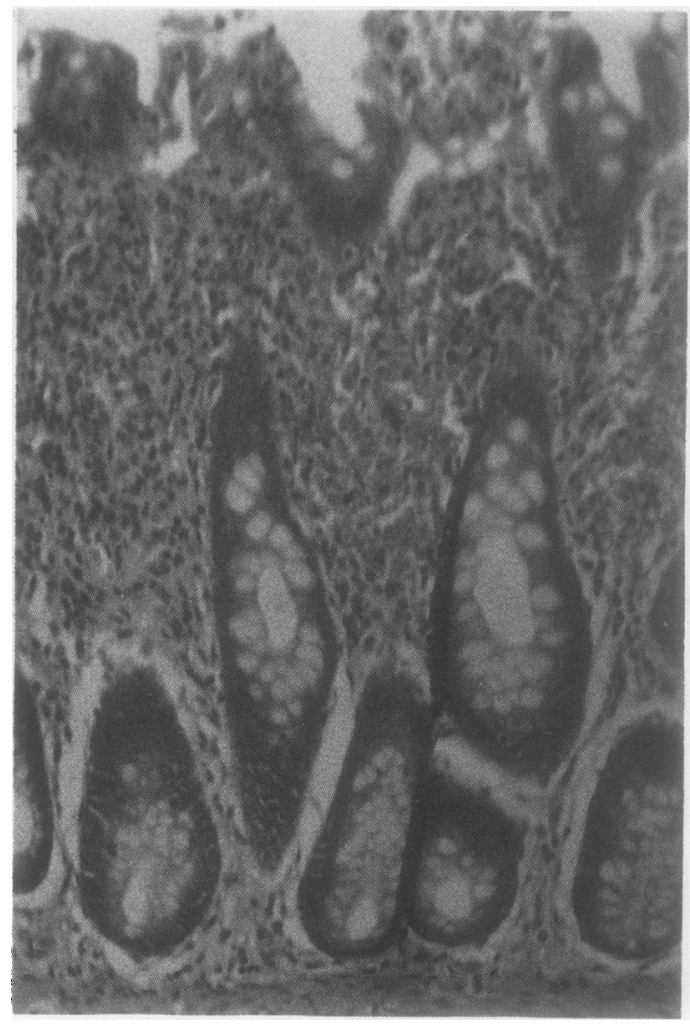

Fig 4 Case 3 (4 and 5 similar): Mild acute inflammation consistent with infective proctitis.

thought to have proctocolitis due to chronic inflammatory bowel disease, based on the sigmoidoscopic appearance, but recovery was complete after 10 days. A previous report describes cases of VTEC infection in one of which the endoscopic appearances were suggestive of ulcerative colitis. ${ }^{18}$ An earlier study of five children who developed haemolytic uraemic syndrome describes their initial diagnoses as ulcerative colitis, based on sigmoidoscopic appearances. ${ }^{29}$ In the four who had biopsies, however, the histological description was non-specific.

Case 4 had such severe abdominal pain that appendectomy was considered soon after admission. Wider knowledge of the condition of haemorrhagic colitis should lessen such diagnostic difficulties.

The importance of studying morphological patterns lies not only in diagnosis and management but also in the insights into pathogenesis that they may provide. VTEC produce at least three toxins, all cytopathic to Vero cells in culture ${ }^{17}$ : VTI (or Shiga-like toxin I) which is indistinguishable from Shiga toxin produced by strains of Shigella dysenteriae type I;VT2 (or Shiga- 
like toxin II), which although structurally similar to Shiga toxin is not neutralised by anti-Shiga or antiVTI toxins; and a Shiga-like toxin II variant. The relative importance of these toxins in the pathogenesis of VTEC infections, including haemolytic uraemic syndrome, is still uncertain.

Animal experiments with VT alone have shown that there is a direct toxic effect on the absorptive epithelial cells of the intestinal villus in rabbits. ${ }^{30}$ This may contribute to the diarrhoea observed in VTEC infection. In gnotobiotic piglets enteric infection with $E$ coli 0157 causes a diarrhoeal illness, although without blood in the stool. ${ }^{31}$ The colon shows luminal exudation and surface ulceration similar to the confluent lesions of pseudomembranous colitis seen in our case 1. Interestingly, the effects in the piglets are the same whether the strain of $E$ coli 0157 used produces high or low concentrations of toxin. The mechanism of bacterial action seems to be by mucosal adherence and brush border dissolution, similar to enteropathogenic $E$ coli, but then progresses until bacteria are seen to multiply in the lamina propria after destroying the surface and glandular epithelium.

It therefore seems that the bacteria directly damage the intestine in addition to producing toxins which may then have more distant effects once they have reached the bloodstream. The severity of clinical enterocolitis and the triggering factors for haemolytic uraemic syndrome probably depend not only on individual susceptibility, which may be related to age, but also on the relative proportions of toxins produced by the particular infecting organisms. Studies of haemolytic uraemic syndrome have implicated endothelial damage, possibly mediated by free radicals, reduced vascular prostacyclin production, abnormalities of platelet function, red cell haemolysis and reduced fibrinolysis. ${ }^{142}$ These changes are thought to be toxin-mediated.

The changes of pseudomembranous colitis have also been attributed to the action of toxin, usually a cytopathic endotoxin produced by $C$ difficile and neutralised in vitro by antitoxin to Clostridium sordellii. ${ }^{26}$ One possible mechanism suggested is of local ischaemia due to capillary microthrombi in the lamina propria preceded by a local Schwartzman reaction..$^{20}$ Toxin-mediated endothelial damage would therefore be common to both pseudomembranous colitis and haemolytic uraemic syndrome (the latter being more widespread) and may explain the association of both syndromes with VTEC infection.

The clinical presentations of our five cases show considerable variation. Although each case showed some similarities to the history of haemorrhagic colitis as described in case reports, four caused diagnostic problems, at least initially. The duration of bacterial shedding may be short, particularly in adults. ${ }^{5}$ Microbiological investigation should therefore be carried out early in all patients with abdominal pain associated with diarrhoea or rectal bleeding.

\section{References}

1 Riley LW, Remis RS, Helgerson SD, et al. Hemorrhagic colitis associated with a rare Escherichia coli serotype. $N$ Engl $J$ Med 1983;308:681-5.

2 Carter AO, Borczyk AA, Carlson JAK, et al. A severe outbreak of Escherichia coli 0157:H7-associated hemorrhagic colitis in a nursing home. $N$ Engl J Med 1987;317:1496-500.

3 Ryan CA, Tauxe RV, Hosek GW, et al. Escherichia coli 0157:H7 diarrhoea in a nursing home: clinical, epidemiological and pathological findings. J Infect Dis 1986;154:631-8.

4 Riley LW. The epidemiologic, clinical and microbiologic features of hemorrhagic colitis. Ann Rev Microbiol 1987;41:383-407.

5 Pai CH, Gordon R, Sims HV, Bryan LE. Sporadic cases of hemorrhagic colitis associated with Escherichia coli 0157:H7. Ann Intern Med 1984;101:738-42.

6 Morrison DM, Tyrrell DLJ, Jewell LD. Colonic biopsy in verotoxin-induced hemorrhagic colitis and thrombotic thrombocytopenic purpura (TTP). Am J Clin Pathol 1986;86:108-12.

7 Anonymous. Unravelling HUS [Editorial]. Lancet 1987;ii:1437-9.

8 Walker CW, Upson R, Warren RE. Haemorrhagic colitis: detection of verotoxin producing Escherichia coli 0157 in a clinical microbiology laboratory. J Clin Pathol 1988;41:80-4.

9 Smith HR, Rowe B, Gross RJ, Fry NK, Scotland SM. Haemorrhagic colitis and Vero-cytotoxin-producing Escherichia coli in England and Wales. Lancet 1987;i:1062-5.

10 Doyle MP, Schoeni JL. Isolation of Escherichia coli 0157:H7 from retail fresh meats and poultry. Appl Environ Microbiol 1987;53:2394-6.

11 Morgan GM, Newman C, Palmer SR, et al. First recognized community outbreak of haemorrhagic colitis due to verotoxinproducing Escherichia coli 0157:H7 in the UK. Epidemiol Infect 1988;101:83-91.

12 Karmali MA, Arbus GS, Petric M, et al. Hospital-acquired Escherichia coli 0157:H7 associated haemolytic uraemic syndrome in a nurse. Lancet 1988;i:526.

13 Karmali MA, Steele BT, Petric M, Lim C. Sporadic cases of haemolytic-uraemic syndrome associated with faecal cytotoxin and cytotoxin-producing Escherichia coli in stools. Lancet 1983;i:619-20.

14 Neild G. The haemolytic uraemic syndrome: a review. $Q J \mathrm{Med}$ 1987;241:367-76.

15 Karmali MA. Laboratory diagnosis of verotoxin-producing Escherichia coli infections. Clin Microbiol News 1987;9:65-70.

16 Taylor CM, White RHR, Winterborn MH, Rowe B. Haemolyticuraemic syndrome: clinical experience of an outbreak in the West Midlands. Br Med J 1986;292:1513-16.

17 Sack RB. Enterohemorrhagic Escherichia coli. N Engl J Med 1987;317:1535-7.

18 Kelly JK, Pai CK, Jadusingh IH, et al. The histopathology of rectosigmoid biopsies from adults with bloody diarrhoea due to verotoxin-producing Escherichia coli. Am J Clin Pathol 1987;88:78-82.

19 Richardson SE, Karmali MA, Becker LE, Smith CR. The histopathology of the hemolytic uremic syndrome associated with verocytotoxin-producing Escherichia coli infection. Hum Pathol 1988;19:1102-8.

20 Goulston SJM, McGovern VJ. Pseudomembranous colitis. Gut 1965;6:207-12.

21 Price AB, Davies DR. Pseudomembranous colitis. J Clin Pathol 1977;30:1-12.

22 Wald A, Mendelow H, Bartlett JG. Non-antibiotic-associated pseudomembranous colitis due to toxin-producing Clostridia. Ann Intern Med 1980;92:798-9.

23 Schwartz JN, Hamilton JP, Fekety R, et al. Ampicillin-induced enterocolitis: Implication of toxigenic Clostridium perfringens type C. J Pediatr 1980;97:661-3. 
24 Thomson G, Clark AH, Hare K, Spilg WGS. Pseudomembranous colitis after treatment with metronidazole. Br Med J 1981; 282:864-5.

25 Phillips RKS, Glazer G, Borriello SP. Non-Clostridium difficile pseudomembranous colitis responding to both vancomycin and metronidazole. $\mathrm{Br}$ Med J 1981;283:823.

26 Chiu AO, Abraham AA. Pseudomembranous colitis associated with an unidentified species of Clostridium. Am J Clin Pathol 1982;78:398-402.

27 Dickinson RJ, Rampling A, Wight DGD. Spontaneous pseudomembranous colitis not associated with Clostridium difficile. $J$ Infect 1985;10:252-5.

28 Altemeier WA, Hummel RP, Hill EO. Staphylococcal enterocolitis following antibiotic therapy. Ann Surg 1963;157:847-58.

29 Berman W. The hemolytic-uremic syndrome: initial clinical presentation mimicking ulcerative colitis. J Pediatr 1972; 81:275-8.
30 Keenan KP, Sharpnack DD, Collins H, Formal SB, O'Brien AD. Morphologic evaluation of the effects of Shiga toxin and E. coli Shiga-like toxin on the rabbit intestine. Am J Pathol 1986;125:69-80.

31 Tzipori S, Wachsmuth K, Chapman C, et al. The pathogenesis of hemorrhagic colitis caused by Escherichia coli 0157:H7 in gnotobiotic piglets. J Infect Dis 1986;154:712-6.

32 Rose PE, Armour JA, Williams CE, Hill FGH. Verotoxin and neuraminidase induced platelet aggregating activity in plasma: their possible role in the pathogenesis of the haemolytic uraemic syndrome. J Clin Pathol 1985;38:438-41.

Requests for reprints to: Dr J A Harvey, Consultant Histopathologist, Lincoln County Hospital, Sewell Road, Lincoln LN2 5QY, England. 